\title{
Evaluation of Egg Quality Traits of Rhode Island Red and Bovans White Under Intensive Management in Mekelle, Ethiopia
}

\author{
Niraj Kumar ${ }^{1}$, Zinabu Nigus Belay ${ }^{1}$, Yohanes Tekele Asfaw ${ }^{1}$ and Etsay Kebede ${ }^{1}$ \\ 1. (College of Veterinary Medicine, Mekelle University, Ethiopia)
}

\begin{abstract}
Rhode Island Red (RIR) and 600 Bovans white exotic poultry breeds were maintained under intensive management by private poultry farm in Mekelle were studied for external and internal egg qualities. Weight of egg $(\mathrm{g})$, length $(\mathrm{cm})$ and width of egg $(\mathrm{cm})$, shape index, egg shell thickness $(\mathrm{mm})$ and egg shell weight $(g)$ were studied as external egg quality traits while yolk and albumen weight $(g)$, yolk and albumin height $(\mathrm{mm})$, Haugh Unit $(\mathrm{HU})$ and yolk color were recorded as internal egg quality traits of RIR and Bovans White. Among external egg quality Weight, length and width of egg of RIR was significantly higher $(p<0.05)$ than Bovans White while shape index, egg shell thickness and egg shell weight $(g)$ were found to be non significant. Among internal egg quality yolk and albumen weight, yolk and albumin height of RIR was significantly higher $(p<0.05)$ than Bovans White while Haugh Unit $(H U)$ and yolk color were found to be non significant.
\end{abstract}

Key words; RIR, Bovans White, egg quality, Mekelle

\section{Introduction}

The total poultry population at country level is estimated to be about 50.38 million and with regard to breed, 96.9 percent, 0.54 percent and 2.56 percent of the total poultry were reported to be indigenous, hybrid and exotic, respectively [1]. From the total population of chicken in Ethiopia, 99\% are raised under the traditional back yard system of management, while $1 \%$ is under intensive management system. The traditional poultry production system is characterized by small flock sizes, low input and output and periodic devastation of the flock by disease [2].

The Ethiopian indigenous chickens are characterized by slow growth, late maturity and low production performance. The mean annual egg production of indigenous chickens is estimated at 60 small eggs with thick shells and a deep yellow yolk color [3]. The egg laying period and number of eggs laid per period are to some extent higher in urban than in rural areas [4]. The carcass weight of local chickens at 6 months of age was $559 \mathrm{~g}$ which was significantly lower than that of the $875 \mathrm{~g}$ found for Leghorn [5]. The productivity of local scavenging hens is low, not only because of low egg production potential, but also due to high chick mortality. About 40 $60 \%$ of the chicks hatched die during the first 8 weeks of life $[4,6,7]$ mainly due to disease and predation. About half of the eggs produced have to be hatched to replace chickens that have died [7], and the brooding time of the laying bird is longer, with many brooding cycles required in order to compensate for unsuccessful brooding. The low productivity of indigenous stock can also partially be attributed to the low management standard of the traditional production system. It has been observed that the provision of vaccination, improved feeding, clean water and night time enclosure improves the production performance of indigenous chickens, but not to an economically acceptable level $[5,8]$.

Local chickens are considered to be disease resistant and adapted to their scavenging environmental conditions. However, local chickens kept under the intensive system of management (in confinement) are inferior to exotic stock in health status and characterized by a lack of interest in their environment, wing droppings, huddling at the corner, leg weakness and cannibalism. They are also slow in rate of feathering and exhibit recurrent outbreaks of disease [9]. The percentage mortality from hatching to maturity was significantly higher for local chickens kept under an intensive management system (24\%) compared to the Leghorns (7.3\%) kept under similar condition. Higher mortalities and morbidities have been reported among local birds than White Leghorns when raised under intensive management conditions in Awassa [5], Debre Zeit [10], Arsi [11] and Alemaya [8].

In Ethiopia, the importation of exotic breeds of chicken goes back to the early 1950s. About $99 \%$ of the Ethiopian poultry population consists of indigenous chickens, while the remaining $1 \%$ consists of imported exotic breeds of chickens during the 1970s and 1980s [12]. There has been an increase in the number of exotic breeds of chickens and at present it is estimated that these make up about $2.56 \%$ of the national poultry population [1]. The contribution of exotic poultry to the Ethiopian economy is significantly lower than that of other African countries [3]. All the available evidence indicates that all the imported breeds of chickens performed well under the intensive management system [3]. With an annual human population growth rate of $2.4 \%$, the present 77.4 million Ethiopia's human population will increase to about 149.3 million by the year 
2040 [13]. Thus, the demand for animal products is expected to increase substantially. To meet the everincreasing demand for meat and eggs, introduction of superior/exotic breed has been proposed as one of the plausible option. Production performance of exotic birds in Ethiopian condition needs to be monitored regularly to provide guidelines for policy makers. However, information is limited about the productive performance of exotic birds under intensive system in the study area. Lack of recorded data on the productive performance of chicken makes it difficult to assess the importance and contributions of the past attempts to improve the sector [14]. Egg quality traits are of immense importance to poultry breeding industries [15]. In addition, embryonic development of hen's egg is dependent on traits like egg weight, yolk and albumen weights, genetic line and age of the hen [16]. Thus the major objective of the study was to evaluate the external and internal egg quality traits of two exotic breeds Rhode Island Red (RIR) and Bovans White (BW) under intensive systems of management in Mekelle.

\subsection{Experimental site}

\section{Materials And Methods}

The study was conducted at private poultry farm maintaining RIR and Bovans White under intensive systems of management in Mekelle city. Mekelle is the capital city of Tigray Region and located in the northern extremes of Ethiopia extending from $33^{0} 25^{1}$ to $39^{0} 38^{1}$ north latitude and from $36^{0} 27^{1}$ to $40^{0} 18^{1}$ east longitude at an average altitude of 2000 to 2200 meters above sea level. The mean annual rain fall ranges from $11.3 \mathrm{~mm}$ to $39.1 \mathrm{~mm}$ and the temperature varies from $12^{\circ} \mathrm{C}$ (in November and December) to $27^{\circ} \mathrm{C}$ (in January and March). Mekelle enjoys humid and hot climate and $783 \mathrm{~km}$ from Addis Ababa [17].

\subsection{Management of the birds}

A total of 1300 birds out of which 700 were RIR and 600 were Bovans white exotic poultry breeds were maintained under intensive management by private poultry farm in Mekelle. The chickens were vaccinated against the most common chicken diseases of the study area. The chickens were offered a standard starter diet for a period of eight weeks (brooding period) after that grower ration was fed for an additional period of 14 weeks (ad libitum). The floor was covered with straw to act as absorbent for the faecal droppings. Adequate ventilation and space was ensured to make the birds comfortable. There will be a continuous supply of drinking water. The feeding and water troughs were cleaned daily.

\subsection{Data collection}

On weekly basis, three eggs were randomly chosen from both the breeds during first 15 weeks of egg production. The eggs were measured for weight, length and width with the help of Vernier calipers. The external egg characteristics were determined by egg weight $(\mathrm{g})$, egg length and width $(\mathrm{mm})$, shell weight $(\mathrm{g})$ and thickness $(\mathrm{mm})$ and egg shape index $(\%)$. The determinants of internal egg quality traits are albumen weight $(\mathrm{g})$, albumen height $(\mathrm{mm})$, yolk weight $(\mathrm{g})$, yolk height $(\mathrm{mm})$, yolk color and Haugh Unit $(\%)$. Eggs were individually weighed to the nearest $0.01 \mathrm{~g}$ using an electronic digital balance. Length and width of egg were individually recorded by using a digital caliper. Shape index, then, was calculated by (width/length) x 100 according to [18]. The shell thickness was measured at three different points in the equatorial shell and the calculated average of the three was used. To determine the internal egg quality traits, eggs were broken onto a flat surface. Yolk height and albumen height were measured using a spherometer. Albumen and yolk were carefully detached with the aid of a spatula and weighed separately. Albumen and yolk weight were determined by weighing with electronic balance separately. The yolk color was determined using the Roche color fan; a standard colorimetric system ranged 1-15. Individual Haugh Units (HU) were calculated from the two parameters; height of albumen $(\mathrm{AH})$ and egg weight $(\mathrm{EW})$ using the formula: $\mathrm{HU}=100 \log \left(\mathrm{AH}-1.7 \mathrm{EW}^{0.37}+\right.$ 7.6), where $\mathrm{HU}=$ Haugh Unit, $\mathrm{H}=$ Observed height of the albumen $(\mathrm{mm})$ and $\mathrm{W}=$ weight of the eggs in grams [19].

\subsection{Data management and analysis}

The data were analyzed using SPSS software version 17 [20]. Differences in productive performances and egg quality traits were compared using means generated from one-way analysis of variance (ANOVA).

a.

\section{Results And Discussions}

External egg quality traits

The external egg quality traits of Rhode Island Red (RIR) and Bovans White birds have been shown in Table 1. The RIR had significantly $(\mathrm{p}<0.05)$ higher mean egg weight $(55.56 \pm 1.79 \mathrm{~g})$ than Bovans White $(50.91 \pm 2.03 \mathrm{~g})$. Higher mean egg weight was reported for RIR being $56.50 \pm 7.22 \mathrm{~g}$ under intensive management in tropics [21]. Lower mean egg weight was reported to be $52.5 \pm 2.83 \mathrm{~g}$ for RIR managed by smallholder farmers in northern Ethiopia [22] and 49.07 $\pm 0.60 \mathrm{~g}$ for RIR kept under intensive management in Pakistan [23]. In South 
Africa, $47.9 \pm 0.3 \mathrm{~g}$ reported for medium sized and $57.8 \pm 0.3 \mathrm{~g}$ was reported for large sized eggs of RIR under intensive managemental system [24]. Higher range of mean egg weight was reported for five Bovans White strain to be $62.82 \mathrm{~g}$ to $65.54 \mathrm{~g}$ [25]. The difference in size may be due to different management, age of production, level of egg production and different agro-ecological conditions among different studies. The mean value of length of egg of RIR was found to be $5.65 \pm 0.17 \mathrm{~cm}$ and width of egg was recorded to be $4.38 \pm 0.11 \mathrm{~cm}$. Length and width of eggs RIR was significantly higher $(\mathrm{p}<0.05)$ than that of Bovans White. The relation between egg weight, egg length and width has been reported by some worker [26]. Higher value of mean egg length and width is reported in RIR in tropics [21]. Mean egg length of RIR in tropics is reported to be in agreement with the current findings [27]. Lower mean values were recorded for egg length and width in RIR kept under intensive management in Pakistan [23].

Table 1: External egg quality traits of RIR and WB

\begin{tabular}{|l|l|l|}
\hline \multirow{2}{*}{ Parameter } & RIR & WB \\
\cline { 2 - 3 } & Mean \pm S.E & Mean \pm S.E \\
\hline Weight of egg $(\mathrm{g})$ & $55.56^{\mathrm{a}} \pm 1.79$ & $50.91^{\mathrm{b}} \pm 2.03$ \\
\hline Length of egg $(\mathrm{cm})$ & $5.65^{\mathrm{a}} \pm 0.17$ & $4.98^{\mathrm{b}} \pm 0.19$ \\
\hline Width of egg $(\mathrm{cm})$ & $4.38^{\mathrm{a}} \pm 0.11$ & $3.91^{\mathrm{b}} \pm 0.09$ \\
\hline Shape index & $77.28 \pm 3.21$ & $78.43 \pm 2.88$ \\
\hline Egg shell thickness $(\mathrm{mm})$ & $0.41 \pm 0.04$ & $0.39 \pm 0.03$ \\
\hline Egg shell weight $(\mathrm{g})$ & $5.20 \pm 0.20$ & $5.03 \pm 0.25$ \\
\hline
\end{tabular}

Eggs are available in different shapes. These shapes can be differentiated using shape index (SI). The shapes most often encountered are sharp, normal (standard) and round eggs which are enumerated on the SI as $<72,72-76$, and $>76$ respectively [28]. In the present study, the shapes of eggs of RIR and Bovans White were found to be round. Shape index of RIR did not differ significantly $(\mathrm{p}<0.05)$ with white Bovans. Shape index of RIR was found to be $77.28 \pm 3.21$ while that of Bovans White was $78.43 \pm 2.88$. Lower shape index value to be $73.08 \pm 2.26$ was reported in RIR kept under intensive system in tropics [23].

The eggshell thickness is an important trait for hatchability. For best result of hatchability egg shell thickness should be between 0.33 and $0.35 \mathrm{~mm}$ and few eggs with a shell thickness less than $0.27 \mathrm{~mm}$ will hatch [29]. In the present study, mean egg shell thickness of RIR was found to be $0.41 \pm 0.04 \mathrm{~mm}$ which did not differ significantly with that of Bovans White $(0.39 \pm 0.03 \mathrm{~mm})$. Lower thickness of shell is reported to be $0.35 \mathrm{~mm}$ in RIR under intensive management [27]. The egg shell quality is determined by the weight and the percentage of shell, thickness and the strength. The differences in eggshell quality depend on the environmental conditions and the feed quality and also of strain of layers [30]. Mean egg shell weight of RIR $(5.20 \pm 0.20 \mathrm{~g})$ in the present study did not differ significantly $(\mathrm{p}<0.05)$ with that of Bovans White $(5.03 \pm 0.25 \mathrm{~g})$. Higher mean egg shell weight is reported to be $9.10 \pm 2.23 \mathrm{~g}$ in RIR under intensive management in tropics [21].

\section{b. Internal egg quality traits}

The internal egg quality traits of RIR and Bovans White birds have been shown in Table 2. Mean yolk weight of RIR $(17.20 \pm 1.10 \mathrm{~g})$ was significantly $(\mathrm{p}<0.05)$ higher than that of Bovans White $(15.29 \pm 1.21 \mathrm{~g})$. Lower yolk weight $(11.20 \pm 2.39 \mathrm{~g})$ was reported in RIR in tropics [21]. Higher mean yolk weight $(20 \pm 0.288 \mathrm{~g})$ is reported in RIR kept under intensive management in Pakistan [31]. Mean albumin weight of RIR $(33.05 \pm 2.77 \mathrm{~g})$ was significantly $(p<0.05)$ higher than that of Bovans White $(30.48 \pm 2.56 \mathrm{~g})$. This is coincided with egg weight since the egg components are proportionately correlated with egg weight. Egg weight influences on weight of components of eggs especially egg albumen and yolk were also reported in other works [32,33]. As for egg component of RIR and Bovans White, the result showed positive correlation between egg weight and albumin and yolk weight. Mean yolk height and albumin height of RIR was significantly $(p<0.05)$ higher than that of Bovans White. Mean yolk height and albumin height in RIR was found to be $17.34 \pm 0.76 \mathrm{~mm}$ and $7.87 \pm 0.65 \mathrm{~mm}$ while that in Bovans White were $15.49 \pm 0.63 \mathrm{~mm}$ and $6.37 \pm 0.54 \mathrm{~mm}$ respectively.

Table 2: Internal egg quality traits of RIR and WB

\begin{tabular}{|l|l|l|}
\hline \multirow{2}{*}{ Parameter } & RIR & Bovans White \\
\cline { 2 - 3 } & Mean \pm S.E & Mean \pm S.E \\
\hline Yolk weight (g) & $17.20^{\mathrm{a}} \pm 1.10$ & $15.29^{\mathrm{b}} \pm 1.21$ \\
\hline Albumin weight (g) & $33.05^{\mathrm{a}} \pm 2.77$ & $30.48^{\mathrm{b}} \pm 2.56$ \\
\hline Yolk height (mm) & $17.34^{\mathrm{a}} \pm 0.76$ & $15.49^{\mathrm{b}} \pm 0.63$ \\
\hline Albumin height (mm) & $7.87^{\mathrm{a}} \pm 0.65$ & $6.37^{\mathrm{b}} \pm 0.54$ \\
\hline Haugh Unit (HU) & $83.67 \pm 3.78$ & $82.15 \pm 3.39$ \\
\hline Yolk color & $9.25 \pm 2.75$ & $9.67 \pm 2.25$ \\
\hline
\end{tabular}

The Haugh Unit (HU) is calculated from the height of the inner thick albumen and the weight of an egg and it is considered to be a typical measure of albumen quality. It is generally accepted that the higher the 
Haugh Unit value, the better the quality of the egg. In present study, mean HU of RIR did not differ significantly $(\mathrm{p}<0.05)$ with that of Bovans White. Mean HU in RIR was found to be $83.67 \pm 3.78$ while that in Bovans white was $82.15 \pm 3.39$. Lower mean HU (75.92 \pm 0.30$)$ was reported in RIR under intensive management in tropics [23]. Study has shown in UK that there is consumer resistant to purchase eggs which have HU's below 60, the actual HU figure where resistance to the product determined later by market researchers. Some of the large supermarkets chains in the UK set minimum acceptable level of $70 \mathrm{HU}$ on regular documented tests [34].

Yolk color value for RIR and Bovans White was not significantly $(\mathrm{p}<0.05)$ different in this study. Mean yolk color of RIR was found to be $9.25 \pm 2.75$ while that in Bovans White was $9.67 \pm 2.25$. Yolk color is a key factor in any consumer survey relating to egg quality [35]. Consumer preferences for yolk color are highly subjective and vary widely from country to country. The determinant of yolk color is the xanthophyl (plant pigment) content of the diet consumed [36]. Green grass during scavenging might be responsible for carotenoid deposits in the yolk, which improves the yolk color. Among feed ingredients, only supplemented maize contributes to improved color intensity of the yolk. Thus, if a hen has access to green grass or supplemented feed ingredients containing carotenoids/xanthophylls, it will be enough to give the yolk the color preferred by consumer [37]. Ethiopian consumers have a strong preference for eggs with deep yellow yolk color. Very small sized eggs from the scavenging local chicken with deep yellow yolk color fetch much higher prices compared to larger eggs of improved strains with pale yolk [38].

\section{Conclusion}

The result indicate that egg weight of RIR was higher than White Bovans but no significant difference was found in shape index, shell thickness and Haugh Unit of RIR as well as Bovans White. Haugh Units for the eggs of both the breeds were in acceptable level.

\section{Acknowledgements}

The authors are grateful to Dean and Head, College of Veterinary Medicine for general support during this study.

\section{References}

[1] CSA. 2012/13. Agricultural sample survey. Report on livestock and livestock characteristics. The Federal Democratic republic of Ethiopia, Central Statistical Agency (CSA). Private Peasant Holdings. Statistical Bulletin 570, Addis Ababa, Ethiopia, April, 2013.

[2] Solomon Demeke, 2007. Comparative nutritive value and protein qualities of Atella and industrial brewers grains in poultry ration in Ethiopia.Livestock Research for rural Development. The International Journal for Research into Sustainable Developing World Agriculture. CIPAV, Cali, Colombia.

[3] Alemu, Yami and Tadelle Dessie, 1997. The Status of Poultry Research and Development in Ethiopia, pp. 40-60. In: Fifth National Conference of Ethiopian Society of Animal Production (ESAP), 15-17 May 1997, Addis Ababa Ethiopia.

[4] CACC (Central Agricultural Census Commission). 2003. Statistical report on farm management practices, livestock and farm managements Central Statistical Authority report of 2004-2005, 2, Addis Ababa, Ethiopia.

[5] Teketel Forsido, 1986. Studies on the Meat Production Potential of Some Local Strains of Chickens in Ethiopia. Ph.D Thesis, J. L. Universty of Giessen, Germany.

[6] Hoyle, E. 1992. Small scale poultry keeping in Wellaita, North Omo region. Farmers Research Project (FRP) Technical Pamphelet No. 3 Ethiopia.

[7] Tadelle Dessie, 1996. Studies on village poultry production systems in the central highlands of Ethiopia. M.Sc Thesis, Swedish University of Agricultural Sciences, Sweden.

[8] Abebe Hassen, 1992. Terminal report on the comparative evaluation of native chicken in the Hararge Administrative region and their crosses with the single comb white Leghorn. Memeographed report. Alemaya University of Agriculture.

[9] Solomon Demeke, 2004. Egg production performance of local and White leghorn hens under intensive and rural household conditions in Ethiopia. Livestock Research for rural development. The International Journal for Research into Sustainable Developing World Agriculture. CIPAV, Cali, Colombia

[10] Abebe Hailu, 1987. Annual progress report of the poultry section of the Debre Zeit agricultural research center. Mimeographed report. Debre Zeit Agricultural Research Center.

[11] Brannang, E. and Persson, S. 1990. Ethiopian animal husbandry . A Handbook. Swedish University of Agricultural Sciences. International Rural development Center. Uppsala, Sweden.

[12] Alamargot, 1987. Avian Physiology of Industrial Poultry Farms in Ethiopia. pp.114-117. Proceedings of the First National Livestock Improvement Conference 11-13 Feb. 1987. Addis Ababa, Ethiopia

[13] FAO (Food and Agriculture Organization of the United Nations) data, 2005. Rome, Italy.

[14] Moges, F., Abera, M. and Tadelle, D. 2010. Assessment of village chicken production system and evaluation of the productive and reproductive performance of local chicken ecotype in Bure district, North West Ethiopia. African J. Agri. Res., 5 (13):1739-1748.

[15] Bain, M. 2005. Recent advances in the assessment of egg shell quality and their future application. World's Poult. Sci. J., 61:268277.

[16] Onagbesan, O., Bruggeman, V., Desmit, L., Debonne, M., Witters, A., Tona, K., Everaert, N. and Decuypere, E. 2007. Gas Exchange During Storage and Incubation of Avian Eggs:effects on Embryogenesis, Hatchability, Chick quality and Post-hatch Growth. World's Poult. Sci. J., 63: 557-573.

[17] MoM, 1998. Mekelle office of metrology. Info. Doc. Note. Mekelle, Ethiopia.

[18] Carter, T.C., 1968. The hen egg. A mathematical model with three parameters. Br. Poult. Sci., 9: 165-171.

[19] Haugh, R. 1937. The Haugh unit of measuring egg quality.US egg Poult. Magazine, 43:552-555.

[20] SPSS. 2007. Statistical Package for Social Sciences SPSS for windows. User's guide: Statistics version 17. Inc. Cary, NC. 
[21] M. Saiful Islam and Ripon Kumar Dutta. 2010. Egg quality traits of indigenous, exotic and crossbred Chickens (gallus domesticus 1.) In rajshahi, Bangladesh. J. Life Earth Sci., Vol. 5: 63-67

[22] Lemlem, A. and Tesfay, Y. 2010. Performance of exotic and indigenous poultry breeds managed by smallholder farmers in northern Ethiopia. Livestock Research for Rural Development. Volume 22, Article \#133. Retrieved March 7, 2014, from http://www.lrrd.org/lrrd22/7/leml22133.htm

[23] Ali, R. Anjum. 2014. Evaluation of egg quality traits among different breeds/strains of chicken locally available in Pakistan. Scientific Journal of Animal Science, 3(1): 27-34

[24] F. de Witt and L.M.J. Schwalbach. 2004. The effect of egg weight on the hatchability and growth performance of New Hampshire and Rhode Island Red chicks. South African Journal of Animal Science 2004, 34 (Supplement 2)

[25] G. Wu, Z. Liu, M.M. Bryant and D.A. Roland, Sr. 2005. Performance Comparison and Nutritional Requirements of Five Commercial Layer Strains in Phase IV. International Journal of Poultry Science 4 (4): 182-186

[26] Danilov, R. 2000. Effect of hens' age on quality of hatching eggs and embryonic development. Proceeding 21st World's Poult. Congress. Montreal, Canada.

[27] K. N. Monira, M. Salahuddin and G. Miah. 2003. Effect of Breed and Holding Period on Egg Quality Characteristics of Chicken. International Journal of Poultry Science 2 (4): 261-263

[28] Ebubekir Altuntaş, Ahmet Şekeroğlu, 2008. Corrigendum to "Effect of egg shape index on mechanical properties of chicken eggs Journal of Food Engineering. 85: 606-612

[29] Khan, M., Khatun, M. and Kibria, A. 2004. Study the Quality of eggs of Different genotypes of chicken under scavenging system at Bangladesh. Pak. J. Biol. Sci., 7 (12):2163-2166.

[30] Zita, L., Tumova, E. and Stolc, L. 2009. Effects of genotype, age and their interaction on egg quality in brown-egg laying hens. Acta Vet., 78:85-91.

[31] Tabinda Khawaja, Sohail Hassan Khan, Nasir Mukhtar, Mian Asghar Ali, Tanveer Ahmed \& Abdul Ghafar. 2012. Comparative study of growth performance, egg production, egg characteristics and haemato-biochemical parameters of Desi, Fayoumi and Rhode Island Red chicken. Journal of Applied Animal Research, 4(4): 182-186

[32] Zhang, L., Ning, Z., Hu, G., Hou Z. and Yang, N. 2005. Heritabilities and genetic and phenotypes correlations of egg quality traits in brown-egg dwarf layers. Poult. Sci., 54:1209-1213.

[33] Aygun, A. and Yetisir, R. 2010. The relationships among egg quality characteristic in different hybrid layers to forced molting programs with and without feed withdrawal. J. Anim. Vet. Adv., 9 (4):710-715.

[34] TSS, 1999. Technical Services and Supplies, QCD instrument Range Manual.York, England, Version 2.1- Release 27E7.

[35] Okeudo, N., Onwuchekwa, C. and Okoli, I. 2003. Effect of oil treatment and length of storage on the internal quality, organoleptic attributes and microbial profile of chicken eggs. Trop. Anim. Prod., 6:63-70.

[36] Silversides, F., Scott, T., Korver, D., Afsharmannesh, R. and Hruby, M. 2006. A study on the interaction of xylase and phytase enzymes in wheat based diets fed to commercial white and brown laying hens. Poult. Sci., 85:297-305.

[37] Zaman, M., Sorensen, P. and Howlider, M. 2004. Egg production performance of a breed and three crossbreds under semiscavenging system of management. Lives. Res. for Rural dev., 16 (8). www.cipav.org.co/1 rrd/1 rrd16/8/zama16060.htm.

[38] Tadelle, D., Kijora, C. and Peters, K. 2003. Indigenous chicken ecotypes in Ethiopia: growth and feed utilization potentials. Int. J. of Poult. Sci., 2:144-152. 